\title{
Vitamin E and Antioxidants Content of Portulaca oleracea L. Form Various Altitudes in East Java, Indonesia
}

\author{
F. Deru Dewanti ${ }^{1 *}$, Bambang Pujiasmanto ${ }^{2,3}$, Sukendah $^{1}$, and Ahmad Yunus ${ }^{2,3}$ \\ ${ }^{1}$ Department of Agrotechnology Science, Faculty of Agriculture, Universitas Pembangunan Nasional "Veteran" \\ East Java, Rungkut Madya Gunung Anyar street 60294, Surabaya, Indonesia \\ ${ }^{2}$ Department of Agrotechnology, Faculty of Agriculture, Universitas Sebelas Maret, Jl. Ir. Sutami 36A \\ Kentingan Jebres Surakarta 57126, Indonesia \\ ${ }^{3}$ Center for Biotechnology and Biodiversity Research and Development, Institute of Research and Community \\ Services, Universitas Sebelas Maret, J1. Ir. Sutami 36A Kentingan Jebres Surakarta 57126, Indonesia \\ *Corresponding author: f.derudewanti@gmail.com
}

\begin{abstract}
This study aims to obtain purslane plants as a source of local food and a quality bioactive component from various altitudes in East Java, Indonesia. Purslane planting materials were collected from the lowlands <200 m asl in Surabaya, medium plains 200-800 m asl in Malang DAU, and highlands > 800 $\mathrm{m}$ asl in Batu, Malang. Analysis of vitamin $\mathrm{E}$ was as total tocopherol. The results of the analysis of the content of Portulaca oleraceae L. of vitamin E were as followed: in the highlands $0.1056 \%$, medium lands $0.1253 \%$, and lowlands $1.162 \%$. The analysis showed that Portulaca oleraceae L. could be a source of high quality local food and bioactive components because it contains vitamin $\mathrm{E}$ and antioxidants.
\end{abstract}

Keywords: bioactive components; local food; lowland

Cite this as: Dewanti, F. D., Pujiasmanto, B., Sukendah and Yunus, A. (2021). Vitamin E and Antioxidants Content of Portulaca oleracea L. Form Various Altitudes in East Java, Indonesia. Journal of Biodiversity and Biotechnology. 1(1), 26-28. doi: https://dx.doi.org/10.20961/jbb.v1i1.50384

\section{Introduction}

Public demands for natural food ingredients that have a higher health function, along with the many degenerative diseases, such as cancer, coronary heart disease, diabetes mellitus, liver, kidney failure, etc. One of the plants that have multiple benefits, both as a food with high nutritional value and medicinal properties (functional food), is purslane (Portulaca oleracea L.).

Purslane contain many components of active compounds. Some compounds include organic acids (oxalic acid, caffeine acid, malic acid, and citric acid), alkaloids, coumarin, flavonoids, cardiac glycosides, anthraquinone glycosides, alanine, catecholamines, saponins, and tannins. There are five types of flavonoids in purslane namely kaempferol, apigenin, myricetin, quercetin, and luteolin. Purslane also contains urea, calcium, iron, phosphorus, manganese, copper, and fatty acids, especially omega-3 fatty acids (1). Omega-3 fatty acids are an important chemical component that the body cannot produce. The seeds contain $\beta$-sitosterol. All parts of this plant contain 1-norepinephrine, carbohydrates, fructose, vitamin A, vitamin B1, vitamin $\mathrm{B} 2$, vitamin $\mathrm{E}$ and are rich in ascorbic acid (2) and beta carotene $(3,4)$.

Purslane is a weed that has nutritional value (5). The purslane is used as a source of food that has very good benefits. Purslane has several advantages by looking at its nutritional content, including as a local food resource, easily obtained and cultivated, and affordable. In addition to being a food source, it also has medicinal properties. The quality of purslane plants as quality food requires proper handling during its cultivation, harvest, and post-harvest to maintain good nutritional content. Among the efforts to maintain the quality of secondary metabolite contents is by knowing the effect of altitude on antioxidant activity, phenolic content and flavonoids. This research aimed to obtain purslane plants as a source of quality 
local food and bioactive components from various altitudes in East Java, Indonesia.

\section{Material and Methods}

The study was conducted by taking purslane planting materials from the lowlands $<200 \mathrm{~m}$ above sea level in Surabaya, medium plains 200-800 $\mathrm{m}$ above sea level DAU in Malang, and highlands $>800 \mathrm{~m}$ above sea level in Batu, Malang.

The analysis of vitamin $\mathrm{E}$ was conducted in the Center for Food and Nutrition Studies laboratory at Gadjah Mada University, Jogjakarta, Indonesia.

\section{Analysis of vitamin E as total tocoperol}

Methods: Analysis of vitamin E conducted with a sample weighing of $1 \mathrm{~g}$, dissolved in $10 \mathrm{ml}$ Hexane; then take $1 \mathrm{ml}$ of stock solution, heated in a water bath until only oil remainined. Add $3.5 \mathrm{ml}$ of 2.2 Bipyridine $0.07 \%$, and add $0.5 \mathrm{ml}$ of $\mathrm{FeCl} 30.02 \%$, then dilute to $10 \mathrm{ml}$ using $96 \%$ ethanol, Tera at $\lambda 520$ NM (AOAC, 1995).

$$
\begin{gathered}
\% \text { Vit E content }=\frac{\mathrm{Xn} \text { Dilution factor }}{\text { Weight sample }(\mathrm{mg})} \times 100 \% \\
\mathrm{X}=\frac{\mathrm{y}-\alpha}{\mathrm{b}}
\end{gathered}
$$

Examination of vitamin E content in Purslane Plants (code samples 5-23, 5-26 and 5-29)

Purslane samples are washed and drained. After draining, roasted at $60^{\circ} \mathrm{C}$ to dry, then the dried Simplicia is blended and sieved. Simplisia powder weighed as much as 1 gram, put into a $100 \mathrm{ml}$ measuring flask. Add methanol p.a. right up to the mark. Ultrasonication for 30 minutes. Shake with hands for 1 minute then let it settle. Take the methanol extract and filter it with a 0.45 -micron membrane filter. The filtrate analyzed by HPLC. Instrument $=$ Agilent 1100 Series HPLC with autosampler and PDA detector. Column $=$ Merck LiChrosper $100 \mathrm{RP}-18,4 \times 250 \mathrm{~mm}, 5$ um. Eluent $=100 \%$ methanol $1 \mathrm{ml} /$ minute. Column temperature $=30^{\circ} \mathrm{C}$. Duration of observation $=284 \mathrm{~nm}$. Injection volume of 100 Ul.

\section{Results and Discussion}

Table 1. Analysis of the content of Portulaca oleracea $\mathrm{L}$.

\begin{tabular}{lccc}
\hline Analysis & $\begin{array}{c}\text { Upland } \\
(>800 \mathrm{~m} \\
\text { asl })\end{array}$ & $\begin{array}{c}\text { Mediumland } \\
(200 \mathrm{~m}-800 \\
\mathrm{m} \mathrm{asl})\end{array}$ & $\begin{array}{c}\text { Lowland } \\
(<200 \mathrm{~m} \\
\text { asl })\end{array}$ \\
\hline Vitamin E (\%) & 0.1056 & 0.1253 & 1.162 \\
\hline
\end{tabular}

\section{Vitamin E}

Antioxidants are substances that can slow down the oxidation processes that harm the body, such as damaged cells, thus accelerating premature aging of the skin, causing cancer, heart disease, etc. Antioxidants found in plants are used to ward off free radicals. Plants that are used as antioxidants usually contain carotenoid compounds, flavonoids, polyphenols, and allyl sulfide. These antioxidants are found in fruits, vegetables, and seeds. The colors of fruits and vegetables are useful pigments as antioxidants.

Antioxidants can protect the skin from the negative effects of free radicals that can cause skin disorders. Types of antioxidants that can benefit the skin are vitamin A, vitamin E, carotenoids, beta-carotene, lycopene, polyphenols, flavonoids, and lutein (6). Vitamin $\mathrm{E}$ is a fat-soluble vitamin that is very useful in addition to being an antioxidant and protects the body from polyunsaturated fatty acids (PUFAs), such as oleic acid, linoleic linolenic acid, and arachidonic acid. Besides, vitamin $\mathrm{E}$ in the body is an antidote to free radicals and oxygen molecules important in preventing the peroxidation of unsaturated fatty acid membranes (7).

Vitamin $\mathrm{E}$ is an efficient stopping reaction for the cause of free radicals in the fat membrane because the form of free radicals is stabilized by resonance. Therefore the vitamin E radical has a small tendency to extract a hydrogen atom from another compound and spread the reaction. Vitamin E radicals can also regenerate in the presence of vitamin $\mathrm{C}$ or glutathione (8). As an antioxidant, vitamin $\mathrm{E}$ functions as a hydrogen ion donor capable of changing peroxyl radicals (lipid peroxide yields) into less reactive tocopherol radicals, so it cannot damage the fatty acid chain (9).

The antioxidant mechanisms of tocopherol include the transfer of one hydrogen atom from the 6-hydroxyl group to the chroman ring and the inactivation of oxygen singlets and other reactive species. The phytopillol tocopherol chain is bound to the bilayer cell membrane, while the active chroman ring is located on the cell surface. This unique structure causes tocopherol to work effectively as an antioxidant and can be regenerated through reactions with other antioxidants such as ascorbic acid (10). The analysis of vitamin $\mathrm{E}$ based on altitude were $0.1056 \%$ in the highlands, $0.1253 \%$ in the middle plains, and $1.162 \%$ in the lowlands. 


\section{Conclusion}

Based on the results of the study, the analysis of the content of Portulaca oleraceae L. Analysis of vitamin E at highland $0.1056 \%$, medium plain $0.1253 \%$, and lowland $1.162 \%$. This shows that Portulaca oleraceae L. can be a source of quality local food and bioactive components because it contains vitamin $\mathrm{E}$ and antioxidants.

\section{Acknowledgments}

All the authors contributed conducted the experiment and prepared the paper.

\section{Conflict of Interest}

All authors declare" no conflicts of interest" inthis section.

\section{References}

1. Palaniswamy UR, McAvoy RJ, Bible BB. Omega-3 fatty acid concentration in purslane (Portulaca oleraceae) is altered by photosynthetic photon flux. J Am Soc Hortic Sci. 2001;126(5):537-43.

2. Hariana H. Tumbuhan obat dan khasiatnya seri 3 agrisehat. Seri 2. Jakarta: Swadaya; 2005. 14 p.

3. Liu L, Howe P, Zhou YF, Xu ZQ, Hocart $\mathrm{C}$, Zhang R. Fatty acids and $\beta$-carotene in Australian purslane (Portulaca oleracea) varieties. J Chromatogr A. 2000;893(1):207-13.

4. Barbosa-Filho JM, Alencar AA, Nunes XP, Tomaz ACA, Sena-Filho JG, Athayde-Filho PF, Silva MS, Souza MFV, Da-Cunha EVL. Sources of alpha, beta, gamma, delta and epsiloncarotenes: A twentieth century review. Rev Bras Farmacogn. 2008;18(1):13554.

5. Sudhakar D, Kishore RK, Parthasarathy PR. Portulaca oleracea L. extract ameliorates the cisplatin-induced toxicity in chick embryonic liver. Indian $\mathbf{J}$ Biochem Biophys. 2010;47(3):185-9.

6. Widyastuti W, Kusuma AE, Nurlaili N, Sukmawati F. Antioxidant and Sunscreen Activities of Ethanol Extract of Strawberry Leaves (Fragaria $x$ ananassa A.N. Duchesne). J Sains Farm Klin. 2016;3(1):19-24.

7. Burke J, Fayaz S, Graham K, Matthew R, Field M. Peer-assisted learning in the acquisition of clinical skills: A supplementary approach to musculoskeletal system training. Med Teach. 2007;29(6):577-82.

8. Berdanier C, Dwyer J, Feldman E. Handbook of nutrition and food. 2nd ed. USA: CRC Press; 2008. 221-226 p.

9. Winarsi H. Antioksidan alami dan radikal. Yogyakarta: Kanisius; 2007. 189-190 p.

10. Salonen, JT, Nyysso“ nen K, Salonen R, Porkkala-Sarataho E, Tuomainen TP, Diczfalusy U. Lipoprotein Oxidation and Progression of Carotid Atherosclerosis. Circulation. 1997;95(4):840-5. 